\section{Implementasi Rencana Aksi \\ Nasional Bela Negara \\ Berdasarkan Instruksi Presiden \\ Nomor 7 Tahun 2018 Oleh \\ Dewan Ketahanan Nasional Republik Indonesia}

\section{Andika Widiyanto' ${ }^{1}, \mathrm{M}$ Dian \\ Hikmawan $^{2}$, Riswanda ${ }^{3}$}

1Program Studi Ilmu Pemerintahan,

Universitas Sultan Ageng Tirtayasa, Indonesia

2Program Studi Ilmu Pemerintahan, Universitas Sultan Ageng Tirtayasa, Indonesia

3 Program Studi Ilmu Pemerintahan, Universitas Sultan Ageng Tirtayasa, Indonesia

*Korespondensi Penulis. E-mail: dian.hikmawan@untirta.ac.id

\begin{abstract}
Abstrak
Ideologi yang merupakan instrumen penting dalam menjadi suatu acuan nilai bagi kehidupan berbangsa dan bernegara serta menjadi nilai yang menjaga keutuhan suatu bangsa. Oleh karena itu, ideologi harus selalu dipahami dengan baik oleh setiap warga negaranya, sehingga dinamika kehidupan berbangsa dan bernegara tidak melenceng dari nilai yang termuat dalam suatu ideologi. Pancasila sebagai ideologi yang mempersatukan berbagai pemikiran dari tiap-tiap warga negaranya, tentunya perlu dipahami dengan baik, sehingga dinamika kehidupan berbangsa dan bernegara tidak mengalami gejolak ataupun perpecahan. Dalam melakukan penguatan pemahaman nilai-nilai Pancasila tentu harus diupayakan oleh pemerintah selaku penyelenggara
\end{abstract}

negara. Lahirnya Instruksi Presiden Nomor 7 Tahun 2018 mengenai Rencana Aksi Nasional Bela Negara, menjadi gambaran bahwa pemerintah tengah mengupayakan penguatan pemahaman nilai-nilai Pancasila yang saat ini mengalami penurunan akibat keteledoran pemerintah yang melaksanakan kegiatan yang bersifat kaku dan monoton. Hal ini tentu menjadi pekerjaan rumah bagi pemerintah beserta masyarakat Indonesia untuk menjaga keutuhan dan kesatuan bangsa. Sebagai contoh, adanya aksi massa yang menonjolkan identitas keagamaan/etnis/kesukuan tentu hal ini menegasikan nilai-nilai persatuan didalam Pancasila. Kasus intoleran, terorisme, dan konflik-konflik vertikal/horizontal yang tengah terjadi di masyarakat. Seiring dengan kemajuan dan perkembangan zaman, upaya yang dilakukan pemerintah dalam memperkuat pemahaman ideologi Pancasila seharusnya tidak bersifat monoton, oleh karenanya perlu modifikasi kegiatan yang lebih bersifat fleksibel dan mengikat semua golongan.

Kata kunci: Implementasi, Pancasila, Bela Negara

\section{Abstract}

Ideology which is an important instrument in being a reference value for the life of the nation and state as well as a value that maintains the integrity of a nation. Therefore, ideology must always be well understood by every citizen, so that the dynamics of national and state life do not deviate from the values contained in an ideology. Pancasila (Five Principal of Indonesia) as an ideology that unites the various thoughts of each of its citizens, certainly needs to be well understood, so that the dynamics of national and state life do not experience 
turmoil or division. In strengthening the understanding of the values of Pancasila, of course, efforts must be made by the government as the state organizer. The birth of Presidential Instruction No. 7 of 2018 concerning the National Defense Action Plan, illustrates that the government is working to strengthen the understanding of Pancasila values that are currently experiencing a decline due to government negligence in carrying out activities that are rigid and monotonous. This is certainly a homework for the government and the people of Indonesia to maintain the integrity and integrity of the nation. For example, a mass action that emphasizes religious / ethnic / ethnic identity certainly negates the values of unity within Pancasila. Cases of intolerance, terrorism, and vertical / horizontal conflicts that are happening in the community. Along with the progress and development of the times, the efforts made by the government in strengthening the understanding of the ideology of Pancasila should not be monotonous, therefore it is necessary to modify activities that are more flexible and binding on all groups.

Keywords : Implemantation, Pancasila, National Defense.

\section{A. PENDAHULUAN}

Berdasarkan perjalanan peradaban didunia, dimana banyak melahirkan pemikiran-pemikiran yang menjadi landasan filosofis berjalannya suatu tatanan kehidupan berbangsa dan bernegara. Seperti Uni Soviet misalnya, yang merupakan salah satu yang pernah menjadi negara yang masuk dalam percaturan kekuasaan dunia dan merupakan seteru daripada beberapa negara- negara lain seperti misalnya, Amerika Serikat. Negara ini ialah Negara Komunis terbesar pada saat itu, oleh karena itu tidak dapat dipandang sebelah mata kekuatan politiknya, sejak berdiri pada tanggal 25 Oktober 1927, bahkan setelah 3 tahun kemudian, yakni sejak 1920 pemimpin Uni Soviet ialah Vladimir Lenin bertekad kuat untuk melebarkan sayap komunis keluar dari Eropa Timur.

Ketika masa kejayaannya, Uni Soviet yang saat itu merupakan kesatuan dari beberapa negara, mampu memberikan pengaruhnya dengan menanamkan paham komunisenya dibeberapa Negara di luar dari Eropa Timur. Akan tetapi pada perkembangannya, justru terjadi kegagalan yang di alami Uni Soviet dalam menyatukan negaranegara yang menjadi bagian dari Uni Soviet. Kuatnya keyakinan atas ego suatu etnik tertentu masih sangat terasa, akibatnya tiap-tiap Negara bagian daripada Uni Soviet masih kental dengan nuansa etnik kedaerahan masing-masing. Hal ini yang kemudian berdampak pada memudarnya rasa persatuan yang dimiliki rakyat Uni Soviet saat itu, sehinngga kemudian faktor inilah yang menyebabkan keruntuhan negara Uni Soviet.

Pemikiran yang menjadi landasan filosofis atau yang dikatakan oleh Soekarno sebagai Philosophisce Grondslag yang kemudian ditetapkan pada 1 Juni 1945 Pancasila sebagai dasar bagi Indonesia untuk merdeka. Meskipun 
Undang-Undang Dasar 1945 sejak sehari setelah Proklamasi

Kemerdekaan bangsa Indonesia telah mengalami amandemen, namun didalam mukaddimah-nya selalu menegaskan, bahwa didalam menyusun kemerdekaan ialah harus berdasarkan pada Pancasila, yang didalamnya terkandung nilai-nilai yang saling berkaitan. Dan Pancasila yang merupakan "Jenius Nusantara" yang telah diwariskan oleh para pendiri bangsa kepada kita yaitu sebuah dasar dan pandangan hidup negara yang menjadi jiwa atas konstitusi UUD 1945 (Latif, 2011).

Dalam pandangan Soekarno manyatakan, "Tidak ada dua bangsa yang cara berjoangnya sama. Setiap bangsa memiliki cara berjuangnya sendiri, mempunyai karakteristiknya sendiri." Oleh karena itu pada hakekatnya setiap bangsa termasuk bangsa Indonesia mempunyai kepribadian sendiri. Yang mana kepribadian itu seharusnya tercermin didalam pelbagai hal baik secara budaya, hukum, sosial, politik, ekonomi, dan lingkungan. Memudarnya keyakinan terhadap Pancasila menghasilkan gambaran suatu peristiwa yang terjadi dalam kehidupan bernegara saat ini merupakan permasalahan yang akut, baik dalam lini pemerintahan ataupun sosial masyarakatnya.

Ditetapkannya Pancasila sebagai dasar Indonesia merdeka pada 1 Juni 1945 merupakan suatu nilai penting bagi bangsa Indonesia dalam membangun kehidupan berbangsa dan bernegara. Kehendak untuk membangun kehidupan yang merdeka, bersatu, berdaulat, adil dan makmur yang tertuang dalam pembukaan UUD 1945 tentu hanya dapat dicapai apabila memposisikan kembali Pancasila sebagai keyakinan standar dan falsafah bangsa sehingga segala aspek kehidupan budaya, hukum atau kebijakan, sosial, politik, ekonomi, dan lingkungan berjalan sesuai dengan Pancasila sebagai dasar Indonesia merdeka.

Pancasila yang semakin hari semakin melemah akibat keteledoran, ketidaktaatan, dan penyelewengan atas nilai-nilai Pancasila oleh bangsa sendiri, terutama oleh lembaga negara, bintang pemimpin itu pun redup tertutup kabut, dan pelan-pelan timbul kegelapan dalam rumah kebangsaan (Latif, 2011). Lemahnya pemaknaan Pancasila sebagai falsafah bangsa Indonesia menjadi pekerjaan rumah yang tak kunjung usai. Di era digital seperti saat ini sangat memberikan dampak yang besar bagi kehidupan budaya bangsa Indonesia, seperti modernisasi dan westernisasi yang banyak menjadikan masyarakat Indonesia hari ini cenderung berkiblat budaya terhadap nilai-nilai budaya barat, sehingga hal ini mencabut nilai-nilai budaya asli yang menjadi jati diri bangsa Indonesia.

Lemahnya pemaknaan Pancasila saat ini menjadi akibat menuculnya perilaku untuk mencontek pemikiran lain sehingga Pancasila tidak lagi dijadikan sebagai keyakinan standar dalam kehidupan berbangsa dan bernegara di Indonesia. Dalam 
(Soekarno, 2017) Soekarno mengatakan bahwa "national unity can only be preserved upon a basic which is larger than the nation it self" yang artinya bahwa sebuah persatuan hanya dapat terjaga dan terpelihara kekal dan abadi jika persatuan nasional itu bersandar pada satu nilai yang lebih luas daripada bangsanya itu sendiri. Persoalan disintegrasi yang hari ini banyak terjadi di nasional menginterpretasikan bahwa Pancasila sebagai Dasar Negara semakin melemah.

Akutnya krisis yang kita hadapi mengisyaratkan bahwa untuk memulihkannya, kita memerlukan lebih dari sekedar politics as usual. Kita memerlukan visi politik baru. Peribahasa mengatakan, "Where there is no vision, the people perish." Visi ataupun tujuan suatu bangsa itu harus berdasarkan pertimbangan yang pada kenyataannya krisis nasional saat ini berakar jauh pada krisis moral yang melanda jiwa bangsa. Tentu harus dilakukan suatu usaha "penyembuhan" untuk memperkuat kembali nilai fundamen etis dan karakter bangsa berlandaskan pandangan hidup bangsa Indonesia itu sendiri (Latif, 2018). Sehingga lemahnya pemaknaan Pancasila saat ini diupayakan oleh Pemerintah untuk melakukan penggiatan penguatan nilai-nilai Pancasila melalui programprogram yang dilaksanakan oleh Lembaga Negara ataupun daerah.

Indonesia yang saat ini bisa dikatakan sedang mengalami krisis multidimensional. Kehidupan politik yang saat ini cenderung berkembang secara teknis, namun mengalami kemunduran secara etik, yang mana kemudian demokrasi justru banyak melahirkan koruptor, kebebasan informasi justru banyak memunculkan sensasi dan kebohongan atau hoax (Latif, 2018). Dalam hal ini maka perlu ada upaya signifikan dari pada pemerintah selaku pemangku kebijakan tertinggi dalam tatanan kenegaraan untuk mengembalikan nilai etik kehidupan berbangsa dan bernegara masyarakat Indonesia sesuai dengan nilai-nilai Pancasila.

Persoalan lemahnya pemaknaan Pancasila saat ini pun menjadi persoalan yang sangat urgen, hal ini dilihat dengan adanya beberapa aturan yang dikeluarkan guna menguatkan kembali nilai-nilai Pancasila, yakni Peraturan Menteri Dalam Negeri nomor 7 tahun 2012 serta Instruksi Presiden nomor 7 tahun 2018. Adapun yang terkait dan menjadi penanggung jawab daripada upaya untuk menguatkan kembali nilai-nilai Pancasila yakni Dewam Ketahanan Nasional dan Seluruh Kementerian Koordinator terkait, yang memiliki kewenangan dalam pelaksanaan Rencana Aksi Nasional Bela Negara dalam konteks penguatan nilai-nilai Pancasila.

\section{B. TEORI (Literature Review)}

Adanya beberapa gejala sosial yang mengisyaratkan bahwa nilainilai Pancasila belum teraplikasikan dengan baik tentu terdapat dibeberapa daerah. Isu mengenai 
Vol.1 No.2 Desember 2019

keagamaan misalnya, yang cenderung bersifat politis karena status keagamaan yang naik diatas panggung politik. Hal ini tentu mengisyaratkan bahwa keutuhan dalam bingkai persatuan belum terjalin dengan baik antara umat beragama. Lain hal misalnya terjadi di Banten, mengenai isu pembakaran rumah ibadah di salah satu tempat di Banten, yaitu di Lebak. Persoalan ini tentu menjadi pertanda dan perhatian khusus bagi pemerintah untuk mengembalikan kehidupan masyarakat di Banten supaya lebih guyub dan harmonis.

Dalam hal yang lebih sederhana misalnya, mengenai etnosentrisme yang masih kental terasa di beberapa wilayah di Indonesia yang dalam hal ini mengenai dukungan terhadap olahraga seperti sepak bola. Isu etnosentrisme yang kental terasa juga kerap kali menjadi pemicu atas perpecahan yang biasanya terjadi di kalangan muda. Hal ini tentu menandakan bahwa dari generasi ke generasi nilai-nilai Pancasila semakin mengalami pelemahan, yang dimungkinkan karena metoda dalam pelaksanaan program penguatan nilai-nilai Pancasila yang sudah tidak relevan, sehingga perlu adanya modifikasi dalam menyampaikan dan menanamkan kembali nilai-nilai Pancasila. Adanya terobosan terbaru dari pemerintah yang menetapkan Instruksi Presiden Nomor 7 Tahun 2018 diharapakan mampu menjadi alternatif baru dalam menguatkan nilai-nilai Pancasila.
Adanya ancaman terhadap ideologi Pancasila seperti terorisme, radikalisme, separatism, dan komunisme tentu menjadi tantangan ekstra bagi pemerintah Indonesia dalam menjaga keutuhan Negara Kesatuan Republik Indonesia. Sehingga dalam Inpres Nomor 7 Tahun 2018 tersebut mengenai permasalahan ancaman ideologi yang mana terdapat penyebaranpenyebaran ideologi yang bertentangan dengan Pancasila.

Melalui penelitian ini tentu bertujuan untuk memberikan masukan pada pemerintah pusat bersama dengan pemerintah daerah yang berwenang melakukan koordinasi dan kerjasama dalam upaya menggiatkan kembali nilainilai Pancasila, sehingga penguatan nilai-nilai Pancasila dapat dilaksanakan dengan tepat, sinergis, dan menyeluruh kepada seluruh elemen masyarakat di Indonesia.

\section{METODE}

Penelitian yang berjudul "Implementasi Rencana Aksi Nasional Bela Negara Berdasarkan Instruksi Presiden Nomor 7 Tahun 2018" ini merupakan suatu pembahasan yang muncul dikarenakan fenomenafenomena sosial dan politik yang terjadi di Indonesia, dimana fenomena yang terjadi merupakan suatu interpretasi yang memperlihatkan terjadinya pergeseran/penyimpangan pikiran atau perilaku yang bertentangan dengan Pancasila sebagai dasar 
negara dan pandangan hidup bangsa Indonesia.

Penelitian ini dilakukan dengan menguraikan data mengenai upaya yang dilakukan oleh pemerintah terhadap komitmen nasional untuk melakukan penggiatan nilai-nilai Pancasila. Pemerintah dalam hal ini tentu memiliki kewenangan yang luas dan keharusan untuk melakukan penguatan nilai-nilai Pancasila guna menjaga kerukunan dan ke-Bhineka Tunggal Ika-an yang melekat pada bangsa Indonesia.

Metodologi Kualitatif tentu menjadi metoda yang tepat yang dijadikan oleh peneliti sebagai alat yang digunakan untuk membedah permasalahan terkait melemahnya pemaknaan nilai-nilai Pancasila dan adanya ancaman pertentangan ideologi yang dapat berakibat mengganti ideologi Pancasila. Metoda ini dianggap tepat oleh peneliti karena data yang dibutuhkan oleh peneliti perlu diuraikan secara mendalam dan dinamis. Sehingga peneliti akan menentukan informan yang memiliki keterkaitan dan ahli atau berkompetensi dalam bidang yang membahas mengenai nilai-nilai Pancasila

Dalam penelitian ini, peneliti menggunakan metode penelitian dengan pendekatan studi kasus. Stake dalam (Cresswell, 2007) menyatakan bahwa:

"Studi kasus bukanlah metodologi, melainkan pilihan tentang sesuatu yang hendak dipelajari (yaitu, kasus dalam sistem terbatas, yang dibatasi oleh waktu dan tempat), yang lain menganggapnya sebagai strategi penelitian, metodologi, atau strategi riset komprehensif (Denzil \& Lincoln, 2005, Merriam, 1998, Yin, 2009)."

Kemudian di dalam pendekatan studi kasus, metoda yang digunakan tetaplah kualitatif. Dimana peneliti melakukan serangkaian aktifitas pengamatan dan wawancara. Meskipun data yang nantinya digunakan bersifat statistik namun data tersebut hanya digunakan sebagai pelengkap guna menguraikan permasalahan secara komprehensif. Dalam penelitian ini, kasus yang diangkat dalam pembahasan Implementasi Rencana Aksi Nasional Bela Negara berdasarkan Instruksi Presiden Nomor 7 Tahun 2018 dikarenakan adanya ancaman faktual yang bertentangan dengan ideologi Pancasila yakni Terorisme, Radikalisme, Seperatisme, dan Komunisme.

\section{HASIL DAN PEMBAHASAN}

1. Kepentingan-kepentingan yang mempengaruhi dalam perumusan Rencana Aksi Nasional Bela Negara

Kepentingan yang terlibat dalam pembuatan kebijakan tentu memberikan pengaruh bagi bentuk kebijakan yang akan dihasilkan. Berdasarkan hasil wawancara yang dilakukan oleh peneliti pada 9 April 2019 pukul 11.08 dengan Tim Dewan Ketahanan Nasional yaitu Kolonel (AU) Oktav Siagian selaku Tim 
Analisis Kebijakan Kedeputian Sistem Nasional, yang menyatakan :

"Sebelum di amandemen perspektif bela negara didalam uu hanya dikategorikan sebagai ranah militer atau pertahanan. Namun saat ini bela negara bukan hanya menyangkut perihal militer namun sudah meluas ke ranah masyarakat. Wantannas disini ditunjuk sebagai pelaksana kordinator bela negara di seluruh lembaga dan kementerian. Bela negara dilakukan berdasarkan karakteristik masyarakat. Adapun tahap pelaksanaan yaitu, pembuatan modul utama yang menjadi rujukan kementerian negara, pelaksanaan munas, rembug nasional, internalisasi (tot), tahap aksi gerakan, tahap pelaporan langsung ke presiden." (Wawancara Kol. AU Oktav Siagian, pada 9 April 2019.)

Dalam pelaksanaan Rencana Aksi Nasional Bela negara yang berdasarkan adanya kebijakan Instruksi Presiden Nomor 7 Tahun 2018 yang kemudian Presiden menunjuk Dewan Ketahanan Nasional Republik Indonesia sebagai pelaksana sekaligus koordinator bela negara di seluruh lembaga dan kementerian. Adapun bentuk bela negara yang hendak ingin dilaksanakan oleh pemerintah saat ini ialah bela negara yang lahir berdasarkan karakteristik lembaga ataupun kementerian, karakteristik pemerintah daerah dengan kearifan lokal yang hendaknya diwujudkan menjadi fondasi nilai-nilai bela negara. Adanya keinginan untuk menguatkan kembali rasa cinta tanah air, menguatkan nilai-nilai Pancasila disegala segmen lapisan masyarakat, serta menumbuhkan semangat bela negara tentu juga menjadi kepentingan pemerintah daerah, yang dalam hal ini ialah pemerintah daerah Provinsi Banten.

Berdasarkan hasil wawancara dengan Kepala Sub Bidang Wawasan Kebangsaan Badan Kesbangpol Provinsi Banten pada 3 Mei 2019, beliau menjelaskan bahwa :

"Di Banten termasuk kedalam zona yang rawan kedalam isu terorisme, dan radikalisme, dan gerakangerakan yang bertentangan dan tidak diakui oleh negara. Program bela negara ini mesti kokoh guna menanggulangi kemungkinan terorisme, radikalisme dan separatisme. Lembaga pemerintah pusat dan pemerintah daerah tentu harus lebih serius dalam menyelesaikan ancaman ideologi, khususnya di Banten. Program Bela Negara ini merupakan kegiatan yang penting yang setiap tahun konsisten kami laksanakan guna mencegah radikalisme." (Wawancara Agus Kasubid Wasbang Kesbangpol Provinsi Banten, 3 Mei 2019)

Banten sebagai salah satu zona yang dapat dikatakan rawan terhadap persoalan terorisme, dan radikalisme, dan gerakan-gerakan yang tidak diakui oleh negara. Dalam rangka menanggulangi permasalahan tersebut, Badan Kesbangpol Provinsi Banten berkepentingan dalam rangka memberikan pengaruh dalam 
menyelesaikan permasalahan radikalisme, terorisme, dan ancamanancaman ideologis lainnya.

Berbagai tantangan yang dihadapi bangsa Indonesia saat ini tentu harus segera diselesaikan oleh pemerintah guna menjaga keutuhan dan kesatuan negara Indonesia. Adapun tantangan-tantangan yang sejauh ini harus segera diselesaikan oleh pemerintah, Yudi Latif menjelaskan dalam wawancaranya bersama peneliti;

"Tantangan penguatan pemahaman nilai-nilai Pancasila ini perlu diwujudkan dengan pendirian dan pengembangan pemahaman terhadap . Hal ini diarahkan pada upaya-upaya dalam pembelajaran, pengkajian, pertukaran pikiran, silang inisiatif dalam praksis kehidupan masyarakat dan pemerintahan. Tantangan esklusivisme, ekstrimisme, yang mengarah pada intoleransi, penguatan nilai-nilai Pancasila dalam hal ini adalah melalui pengembangan kewargaan inklusif dimana masingmasing dan semua anak bangsa dapat berkontribusi terhadap kebangsaan Indonesia. Tantangan pelembagaan, penguatan pemahaman nilai-nilai kebangsaan tentu harus diwujudkan dengan pembangunan pelembagaan Pancasila didirikan dan diupayakan dalam kehidupan kebangsaan dan kenegaraan. Hal ini diarahkan pada ranah, kebudayaan, ranah politik, ranah ekonomi." (Wawancara tertulis dengan Yudi Latif selaku Akademisi, pada 8 April 2019)
Tantangan untuk melakukan penguatan nilai-nilai Pancasila, kemudian melakukan pelembagaan Pancasila, guna menyelesaikan permasalahan-permasalahan

esklusivisme, ekstrimisme, radikalisme, serta terorisme haruslah diupayakan secara maksimal oleh seluruh lapisan masyarakat guna menciptakan kehidupan bangsa dan negara yang kental dengan nuansa kekeluargaan dan gotong-royong.

2. Jenis manfaat yang seharusnya dihasilkan dalam implementasi Rencana Aksi Nasional Bela Negara

Penguatan pemahaman nilainilai kebangsaan tentu harus memberikan manfaat yang dirasakan dan memberikan dampak dalam kehidupan sosial-masyarakat. Tiaptiap daerah seharusnya dapat memberikan sumbangsihnya terhadap pengaktualisasian nilai-nilai Pancasila. Yudi Latif dalam wawancaranya bersama peneliti menjelaskan;

"Proses penguatan pemahaman ini perlu dilaksanakan disemua wilayah Indonesia, ternasuk Banten. Proses ini perlu mengangkat Banten untuk "berdiri sama tinggi, duduk sama rendah" dengan wilayah-wilayah lain di Indonesia. Oleh karenanya Banten perlu menggali nilai-nilai luhur yang ada selama ini sebagai perwujudan daripada Pancasila, dengan itu Banten dapat memberikan sumbangan kehidupan Pancasila dalam kehidupan nasional." (Wawancara tertulis dengan Yudi 
Latif selaku Akademisi, pada 8 April 2019)

Adanya pelaksanaan Program Bela Negara ini dilatar belakangi oleh kekhawatiran pemerintah mengenai adanya krisis multidimensi yang melanda bangsa Indonesia, sehingga pelemahan pemahaman mengenai wawasan kebangsaan yang di antaranya pemahaman mengenai Pancasila, UUD 1945, NKRI, dan Bhineka Tunggal Ika. Berdasarkan hasil wawancara yang dilakukan pada hari Selasa 26 Maret 2019 pukul 13.02 WIB dengan Pakar dari Dewan Ketahanan Nasional, Leo Agustino.

"Secara filosofis lahirnya Instruksi Presiden Nomor 7 tahun 2018 dilatarbelakangi karena beberapa persoalan disintegrasi bangsa. Ada beberapa faktor yang mengakibatkan terjadinya disintegrasi bangsa. Banyaknya kemunculan kelompokkelompok kanan ataupun kiri dimana kanan diidentikkan dengan golongan islam dan kiri yang identik dengan golongan komunis, dan termasuk kelompok-kelompok yang ingin mengganti ideologi Pancasila. (Wawancara Leo Agustino, 26 Maret 2019)

Adanya permasalahan disintegrasi yang melanda bangsa Indonesia saat ini memicu kekhawatiran pemerintah sehingga secara responsif pemerintah mengeluarkan kebijakan Instruksi Presiden Nomor 7 Tahun 2018 untuk melakukan Rencana Aksi Nasional Bela Negara. Permasalahan disintegrasi tentu menjadi persoalan yang serius bagi setiap bangsa, khususnya bangsa yang besar seperti Indonesia, adapun permasalahan disintegrasi bangsa ini terjadi dikarenakan beberapa faktor, salah satunya adalah karena munculnya kelompok-kelompok tertentu yang tidak bersepakat dengan Ideologi Pancasila serta berusaha untuk mengganti Ideologi Pancasila dengan Ideologi lainnya. Tentu hal ini juga dipicu karena lemahnya pemahaman masyarakat akan wawasan kebangsaan sehingga mudah terpengaruhi oleh ideologi kelompok lain.

Sejalan dengan yang disampaikan Leo Agustino, adapun wawancara selanjutnya dilakukan kepada Tim Dewan Ketahanan Nasional yaitu Kolonel (AU) Oktav Siagian selaku Tim Analisis Kebijakan Kedeputian Sistem Nasional.

“Inpres no 7 tahun 2018 lahir berdasarkan keprihatinan kita terhadap bangsa yang kini dilanda krisis multidimensi. Karena saat ini ancaman atas kehancuran suatu bangsa bukan hanya muncul dari ranah militer, tetapi banyak sekali segmen yang dapat mengancam, diantaranya adalah ideologi, hoax, radikalisme, dll. Maka pemerintah berpikir harus ada penguatan nilainilai kebangsaan salah satunya adalah pancasila. Memunculkan kembali nilai cinta tanah air, rasa memiliki sebagai bangsa, karena kerapuhan nilai-nilai kebangsaan (Pancasila, NKRI, bhineka, uud 1945) 
dapat menghancurkan suatu bangsa, maka perlu ditumbuhkan nilai-nilai bela negara disetiap WNI". (Wawancara Kol. AU Oktav Siagian, pada 9 April 2019)

Dari penyampaian narasumber mengatakan bahwa krisis multidimensi yang dialami bangsa ini tentu sangat memprihatinkan. Karena ancaman yang menghancurkan suatu bangsa saat ini tidak hanya ditimbulkan dari persoalan militer, melainkan banyak faktor yang juga terjadi di masyarakat yang dapat menghancurkan bangsa Indonesia.

3. Derajat perubahan yang ingin dicapai pasca implementasi Rencana Aksi Nasional Bela Negara

Lahirnya Instruksi Presiden Nomor 7 Tahun 2018 mengenai Rencana Aksi Nasional Bela Negara tentu diharapkan dapat memberikan manfaat yang nyata bagi kehidupan berbangsa dan bernegara di Indonesia. Sehingga manfaat yang diperoleh oleh masyarakat dapat memberikan dampak ataupun perubahan yang signifikan dalam menciptakan masyarakat yang berlandaskan pada nilai-nilai Pancasila dan nilai-nilai kebangsaan lainnya.

Pengaktualisasian nilai-nilai kebangsaan yang merujuk pada nilainilai Pancasila tentu harus teraplikasikan dalam kehidupan sosial-masyarakat. Yudi Latif berpendapat bahwa;

"Gotong-royong sebagai standar terbangunnya kehidupan berbangsa dan bernegara yang sesuai dengan nilai-nilai Pancasila." (Wawancara tertulis dengan Yudi Latif selaku Akademisi, pada 8 April 2019)

Gotong-royong merupakan standar atas teraplikasikannya kehidupan berbangsa dan bernegara yang telah berada pada jalur nilainilai Pancasila. Tentu gotong-royong disini adalah sinergitas yang terbangun di tiap-tiap masyarakat, sinergitas yang terbangun di tiap-tiap lembaga pemerintah pusat dan daerah, dan sinergitas lainnya yang mencerminkan kehidupan bahumembahu dalam membangun kehidupan bernegara yang berkeadilan.

Selain itu, peneliti melakukan wawancara dengan Leo Agustino, selaku pakar dari Dewan Ketahanan Nasional. Wawancara dilakukan pada hari Selasa 26 Maret 2019 pukul 13.02 WIB :

"Sebagai bangsa yang memiliki kewaspadaan nasional, tentu bangsa Indonesia memiliki kewaspadaan terhadap kemunculan-kemunculan ideologi yang bertentangan dengan Pancasila. Adanya kemunculan ideologi-ideologi yang bertentangan dirasa mengganggu nuansa nilai-nilai Pancasila, oleh karenanya perlu dilahirkan suatu kebijakan yang bertujuan untuk mengembalikan nilai-nilai Pancasila, guna mengembalikan kembali keguyuban dalam bernegara" (Wawancara Leo Agustino, 26 Maret 2019) 
Sebagai bangsa yang besar tentu bangsa Indonesia memiliki kewaspadaan terhadap kemunculankemunculan ideologi yang bertentangan dengan ideologi Pancasila serta dianggap mengganggu nuansa dan nilai- nilai Pancasila. Tentu pemerintah harus dengan responsif menanggapi isu yang dapat memecah-belah bangsa Indonesia dengan mengembalikan dan memperkuat kembali keguyuban dalam bernegara berlandaskan kepada Pancasila.

Selain itu Kolonel (AU) Oktav Siagian dalam wawancara yang dilakukan di Skretariat Jenderal Ketahanan Nasional pada 9 April 2019, beliau menambahkan bahwa :

"Banyaknya fenomena politik identitas seharusnya tidak ditonjolkan diranah publik karena dapat mengancam keutuhan berbangsa dan bernegara, oleh karena itu perlu kembali memahami dengan baik nilai-nilai bela negara." (Wawancara Kol. (AU) Oktav Siagian, 9 April 2019)

Fenomena politik identitas menjadi hal yang sangat dikhawatirkan oleh pemerintah karena dapat menjadi penyebab terjadinya perpecahan. Seharusnya identitas merupakan hal privat yang tidak layak ditonjolkan di publik, dalam hal politik misalnya, identitas kedaerahan, agama, suku, ras dan yang lainnya seharusnya tidak menjadi konsumsi dalam kehidupan bernegara. Perbedaan yang ada pada masyarakat Indonesia tentu seharusnya menjadi keindahan untuk saling melengkapi dan saling menghargai.

Perubahan yang sangat diinginkan dari kondisi kehidupan berbangsa dan bernegara pasca di lahirkannya Instruksi Presiden Nomor 7 Tahun 2018 dan dilaksanakannya program Rencana Aksi Nasional Bela Negara tentu adalah kehidupan bernegara yang penuh dengan nuansa kehidupan berbangsa yang guyub, sehingga kehidupan yang terbentuk adalah kehidupan yang aman, damai, dan tenteram.

Namun akibat adanya ketidaksinergisan antara lembaga pemerintah pusat dengan pemerintah daerah menjadikan perubahan yang diharapkan mengalami perlambatan untuk bisa terwujud. Belum sinergisnya antar lembaga penyelenggara Rencana Aksi Nasional Bela Negara ini terlihat dalam wawancara yang dilakukan peneliti dengan narasumber Kasubid Wawasan Kebangsaan Badan Kesatuan Bangsa dan Politik Provinsi Banten.

“Program Bela Negara ini merupakan kegiatan yang penting yang setiap tahun konsisten kami laksanakan guna mencegah radikalisme. Namun terbatasnya anggaran juga menjadi permasalahan yang menjadikan kami hanya mampu melakukan sebagas pencegahan. Tentu semua lini diharapkan mendukung kegiatan bela negara, misalnya dari sektor agama, pertahanan, pemerintah pusat dan 
daerah." (Wawancara Agus Kasubid Wasbang Kesbangpol Provinsi Banten, 3 Mei 2019)

Banten yang merupakan salah satu wilayah yang termasuk kedalam zona rawan akan ancaman radikalisme tentu menjadi keprihatinan pemerintah akan kenyamanan dan ketenteraman masyarakat. Oleh karena itu guna menanggulangi ancaman tersebut program bela negara merupakan salah satu langkah yang perlu dilakukan dengan serius oleh pemerintah. Namun dalam praktisnya pelaksanaan program bela negara mengalami beberapa kendala diantaranya masalah anggaran yang saat ini cenderung diprioritaskan bagi pembangunan infrastruktur. Selain itu, objek dalam pelaksanaan program bela negara yang masih hanya fokus pada kalangan pelajar tentu perlu harus segera diperbaharui dengan melakukan kegiatan yang menguatkan nilai-nilai bela negara di kalangan masyarakat secara luas.

\section{Kedudukan pengambil \\ keputusan terkait Rencana Aksi Nasional Bela Negara}

Dalam penelitian mengenai Implementasi Rencana Aksi Nasional Bela Negara berdasarkan Instruksi Presiden Nomor 7 Tahun 2018 yang tentunya dibuat langsung oleh Presiden dengan dibantu oleh beberapa lembaga negara. Presiden selaku kepala pemerintahan tertinggi di Negara tentu memiliki kedudukan yang strategis untuk mengeluarkan instruksi kebijakan. Kemudian daripada kebijakan tersebut dikoordinasikan kepada Dewan Ketahanan Nasional untuk menjadi koordinator pelaksanaan program Rencana Aksi Nasional Bela Negara.

Dari hasil wawancara langsung yang dilakukan oleh peneliti kepada Kolonel (AU) Oktav Siagian selaku tim Analisis Kebijakan Kedeputian Sistem Nasional Wantannas mengungkapkan bahwa:

"Wantannas disini ditunjuk sebagai pelaksana kordinator bela negara di seluruh lembaga dan kementerian. Bela negara dilakukan berdasarkan karakteristik masyarakat. Adapun tahap pelaksanaan yaitu, pembuatan modul utama yang menjadi rujukan kementerian negara, pelaksanaan munas, rembug nasional, internalisasi (tot), tahap aksi gerakan, tahap pelaporan langsung ke presiden." (Wawancara Kol. (AU) Oktav Siagian, 9 April 2019)

Instruksi Presiden Nomor 7 Tahun 2018 mengenai Rencana Aksi Nasional Bela Negara yang dikeluarkan oleh Presiden yang kemudian menunjuk Dewan Ketahanan Nasional sebagai koordinator bela negara di seluruh kementerian dan lembaga negara. Yang nantinya pelaksanaan program bela negara dilakukan berdasarkan karakteristik kementerian dan masyarakatnya, sehingga masyarakat dapat mengembangkan kearifan lokal sebagai bekal untuk melakukan bela negara. 


\section{Siapa pelaksana program Rencana Aksi Nasional Bela Negara}

Pelaksanaan program Rencana Aksi Nasional Bela Negara yang dikoordinasikan oleh Dewan Ketahanan Nasional, adapun yang ditunjuk sebagai pelaksana Rencana Aksi Nasional Bela Negara berdasarkan Instruksi Presiden Nomor 7 Tahun 2018 ialah kementerian terkait, lembaga negara, pemerintah daerah dan Tentara Nasional Indonesia, serta Kepolisian Republik Indonesia.

Bela negara juga menjadi program rutinitas bagi pemerintah daerah yang dalam hal ini dilaksanakan oleh Badan Kesatuan Bangsa dan Politik Provinsi Banten. Peneliti berhasil melakukan wawancara dengan Agus selaku Kasubid Wawasan Kebangsaan Badan Kesatuan Bangsa dan Politik Provinsi Banten.

"Program bela negara merupakan program yang harus dilaksanakan. Dasar hukum yang saat ini menjadi rujukan bagi kami dalam melaksanakan program bela negara adalah permendagri nomor 71 tahun 2012. Namun jika Inpres Nomor 7 Tahun 2018 kami dari Kesbangpol Provinsi Banten belum mengetahui terkait dengan kebijakan tersebut. Kami Badan Kesbangpol Provinsi Banten baru mendengar adanya Inpres tersebut. Pelaksanaan program bela negara yang saat ini laksanakan oleh kami lebih menyasar pada pelajar dan mahasiswa yang biasanya kami melakukan pembekalan, dan kami rasa ini merupakan langkah dasar guna membimbing generasi penerus kedepan." (Wawancara Agus Kasubid Wasbang Kesbangpol Provinsi Banten, 3 Mei 2019)

Namun yang sangat menjadi perhatian peneliti disini adalah mengenai belum mengetahuinya pelaksana terkait dengan kebijakan yang dikeluarkan oleh Presiden yakni Instruksi Presiden Nomor 7 Tahun2018 mengenai Rencana Aksi Nasional Bela Negara. Hal ini tentu merupakan bentuk gambaran daripada belum sinergisnya pemerintah pusat dengan pelaksana program Rencana Aksi Nasional Bela Negara. Hal ini tentu menjadi permasalahan sinergisitas yang tentunya harus segera diselesaikan guna mempercepat hasil yang diinginkan secara menyeluruh.

5. Sumber daya yang dihasilkan setelah di implementasikannya Rencana Aksi Nasional Bela Negara

Implementasi Rencana Aksi Nasional Bela Negara berdasarkan Instruksi Presiden Nomor 7 Tahun 2018 merupakan gambaran dari kekhawatiran pemerintah mengenai adanya ancaman faktual yang mengganggu nuansa kehidupan berbangsa dan bernegara. Tentu implementasi Rencana Aksi Nasional tersebut seharusnya berbanding lurus dengan sumber daya yang dihasilkan dari pelaksanaan kegiatan bela negara. 
Sebagai seorang akademisi yang cukup memiliki kompetensi dalam wawasan kebangsaan, peneliti melakukan wawancara kepada Yudi Latif, yakni seorang akademisi sekaligus seorang yang pernah menjadi pimpinan Badan Pembinaan Ideologi Pancasila (BPIP). Yudi Latif mengemukakan bahwa:

"Pelaku yang seharusnya terlibat dalam melakukan penguatan pemahaman nilai-nilai kebangsaan ialah (1) kaum muda dengan gagasan-gagasannya yang dapat menjadi prestasi bangsa (2) penyelenggara negara yang saat ini sedang berjuang untuk membuat dan bangsa Indonesia menjadi rumah untuk semua, dan dalam menjalankan kehidupan yang lebih bahagia dan berkeadilan (3) tokoh publik yang perlu menjadi sosok teladan (4) pemikir, termasuk yang sedang bergulat dalam akademik, kebijakan publik, dan riset, yang menyumbangkan keunggulan mereka sebagai keunggulan bangsa (5) kelompok-kelompok yang bergerak dalam segala bidang yang senantiasa membagikan keunggulan-keunggulan prestasi." (Wawancara tertulis dengan Yudi Latif selaku Akademisi, pada 8 April 2019)

\begin{tabular}{lcr}
\multicolumn{1}{c}{ Belum } & terlibatnya & elemen \\
lapisan & masyarakat & secara \\
menyeluruh & seperti halnya & kaum \\
muda, penyelenggara negara & atau \\
pemangku & kebijakan, & tokoh \\
masyarakat, & akademisi, & dan \\
organisasi-organisasi & yang
\end{tabular}

menjadikan penguatan pemahaman Pancasila dan nilai-nilai kebangsaan tidak terselenggara dengan baik, dan belum menyeluruh, apalagi memberikan dampak yang signifikan bagi kehidupan bangsa dan negara Indonesia dengan berhasil menghasilkan sumber daya yang mampu menjadi pelopor bela negara. Badan Kesatuan Bangsa dan Politik Provinsi Banten juga menyasar kalangan pelajar sebagai peserta ataupun objek pelaksanaan program bela negara.

"Pelaksanaan program bela negara yang saat ini laksanakan oleh kami lebih menyasar pada pelajar dan mahasiswa yang biasanya kami melakukan pembekalan, dan kami rasa ini merupakan langkah dasar guna membimbing generasi penerus kedepan." (Wawancara Agus Kasubid Wasbang Kesbangpol Provinsi Banten, 3 Mei 2019)

Tentu ini merupakan langkah baik yang dilakukan oleh pemerintah daerah Provinsi Banten saat ini dalam rangka menguatkan kembali nilainilai Pancasila dan wawasan kebangsaan di kalangan pelajar. Namun dikarenakan urgensinya terhadap persoalan radikalisme, disintegrasi bangsa yang juga banyak terjadi di Provinsi Banten tentu langkah ini masih belum optimal guna menciptakan kehidupan bernegara yang guyub dan lekat dengan nuansa nilai-nilai Pancasila. 
6. Kekuasaan, kepentingankepentingan, strategi aktor yang terlibat dalam perumusan Rencana Aksi Nasional Bela Negara

Dalam konteks pelaksanaan program Rencana Aksi Nasional Bela Negara, tentu kekuasaan, kepentingan serta aktor yang terlibat menjadi sangat penting dalam mempengaruhi keberhasilan pelaksanaan bela negara. Akutnya krisis yang melanda bangsa Indonesia tentu mengharuskan keseriusan pemerintah pusat dan pemerintah daerah dalam mencegah adanya ancaman-ancaman radikalisme, separatisme, serta ancaman terjadinya disintegrasi bangsa.

Dewan Ketahanan Nasional (Wantannas) selaku representasi dari pemerintah pusat dalam mengoordinatori Rencana Aksi Nasional Bela Negara tentu menjadi sosok sentral dalam memberikan pengaruh perubahan bagi kondusifitas kehidupan bernegara.

"Sinergitas antar lembaga negara, kementerian dan pemerintah daerah sudah saling sinergis dalam pelaksanaan bela negara berdasarkan inpres no 7 tahun 2018. Program bela negara sebelumnya telah ada di dalam kementerian terkait namun diperkuat kembali berdasarkan inpres ini, perspektif bela negara juga termasuk kedalam program prioritas pemerintah saat ini yang merujuk pada modul utama." (Wawancara Kol. (AU) Oktav Siagian, 9 April 2019)
Program bela negara yang ada di tiap kementerian dan pemerintah daerah tentu harus diwujudkan dengan merujuk pada modul utama Inpres Nomor 7 Tahun 2018, namun setelah dilakukan penggalian data mendalam ternyata sinergitas antara lembaga negara, pemerintah pusat dan pemerintah daerah belum terbangun secara baik seperti yang telah dipaparkan sebelumnya, bahwa pemerintah daerah Provinsi Banten belum mengetahui adanya Inpres Nomor 7 Tahun 2018 serta rujukan bela negara berdasarkan Rencana Aksi Nasional Bela Negara.

Modul yang belum diperbaharui terkait dengan bela negara menjadikan model gaya lama yang diimplementasikan yang diantaranya masih berupa program-program sosialisasi yang menyasar objek pesertanya pelajar.

"Program bela negara merupakan program yang harus dilaksanakan. Dasar hukum yang saat ini menjadi rujukan bagi kami dalam melaksanakan program bela negara adalah permendagri nomor 71 tahun 2012. Namun jika Inpres Nomor 7 Tahun 2018 kami dari Kesbangpol Provinsi Banten belum mengetahui terkait dengan kebijakan tersebut. Kami Badan Kesbangpol Provinsi Banten baru mendengar adanya Inpres tersebut. Pelaksanaan program bela negara yang saat ini laksanakan oleh kami lebih menyasar pada pelajar dan mahasiswa yang biasanya kami melakukan pembekalan, dan kami rasa ini 
merupakan langkah dasar guna membimbing generasi penerus kedepan." (Wawancara Agus Kasubid Wasbang Kesbangpol Provinsi Banten, 3 Mei 2019)

Belum sinergisnya antara lembaga penyelenggara pemerintah daerah dan pemerintah pusat tentu menjadi kekurangan yang menghambat terwujudnya kehidupan berbangsa dan bernegara yang sesuai dengan nilai-nilai Pancasila. Akutnya krisis yang dihadapi bangsa Indonesia saat ini mengharuskan penguatan nilai-nilai Pancasila dan bela negara di segala lini dan bukan hanya kalangan pelajar. Seperti misalnya kalangan-kalangan masyarakat yang lebih luas, para ekonom, dan para pemangku kebijakan yang juga sangat perlu penguatan nilai-nilai Pancasila.

\section{Karakteristik lembaga dan rezim yang berkuasa dalam mengedepankan kepentingan Rencana Aksi Nasional Bela Negara}
Dalam
mewujudkan

kehidupan bernegara yang guyub dan penuh dengan nuansa kekeluargaan tentu juga harus di dorong dengan keseriusan pemerintah pusat dan pemerintah daerah untuk memperkuat kembali karakter bangsa Indonesia berdasarkan nilainilai Pancasila. Namun belum seriusnya pemerintah pusat dan pemerintah daerah yang saat ini dilihat lebih memprioritaskan program pembangunan infrastruktur menjadikan program Rencana Aksi
Nasional Bela Negara guna mewujudkan penguatan pemahamanpemahaman nila Pancasila mengalami perlambatan.

“Pelaksanaan program bela negara yang dilaksanakan oleh Badan Kesbangpol Provinsi Banten belum menjadi program prioritas bagi Gubernur dan juga pemerintah pusat, yang saat ini lebih cenderung memprioritaskan program pembangunan infrastruktur, pendidikan, dan kesehatan. Di Banten termasuk kedalam zona yang rawan akan isu terorisme, dan radikalisme, dan gerakan-gerakan yang bertentangan dan tidak diakui oleh negara. Program bela negara ini mesti kokoh guna menanggulangi kemungkinan terorisme, radikalisme dan separatisme." (Wawancara Agus Kasubid Wasbang Kesbangpol Provinsi Banten, 3 Mei 2019)

Karakteristik lembaga dan penguasa yang masih belum serius dalam melakukan penguatan nilai bela negara dan nilai-nilai Pancasila tentu menjadi hambatan dalam mewujudkan kehidupan berbangsa dan bernegara yang kondusif, guyub, dan sesuai dengan nilai-nilai Pancasila. Pemerintah yang saat ini lebih cenderung memprioritaskan pembangunan infrastruktur tentu menjadi kendala dalam penganggaran pelaksanaan program Rencana Aski Nasional Bela Negara.

Selain itu, kedudukan hukum Rencana Aksi Nasional Bela Negara yang masih pada level Instruksi Presiden tentu ini menjadi persoalan 
terkait belum terbangunnya karakteristik serius dari pemerintah dalam menghadapi permasalahan ancaman radikalisme, serta disintegrasi bangsa.

"Idealnya kedudukan hukum bela negara ini seharusnya pada level uu dan bukan hanya inpres, tentu ini menjadi kelemahan bagi pemerintah saat ini dalam memfokuskan dalam penguatan nilai-nilai bela negara dan pendalaman penanaman nilai-nilai Pancasila." (Wawancara Kol. (AU) Oktav Siagian, 9 April 2019)

Kedudukan hukum yang ideal tentu menggambarkan keseriusan pemerintah dalam mengupayakan kehendaknya, dalam konteks ini pemerintah belum serius dalam mengupayakan optimalisasi penguatan nilai-nilai Pancasila dan nilai-nilai bela negara. Idealnya kedudukan hukum dalam Rencana Aksi Nasional Bela Negara ini adalah berada pada level Undang-undang.

\section{Tingkat kepatuhan dan adanya respons dari pelaksana ataupun lembaga penyelenggara Rencana Aksi Nasional Bela Negara}

Kepatuhan dan daya tanggap yang responsif tentu menjadi ukuran dari terciptanya sinergitas antar lembaga penyelenggara baik pemerintah pusat dan pemerintah daerah dalam melaksanakan program Rencana Aksi Nasional Bela Negara. Dalam beberapa kesempatan wawancara yang dilakukan oleh peneliti dimana penyelenggara pelaksanaan program bela negara di
Provinsi Banten masih belum mengetahui adanya kebijakan Inpres Nomor 7 Tahun 2018. Sehingga model bela negara yang dilaksanakan adalah program bela negara yang masih menggunakan cara dan gaya lama.

"Kami dari Kesbangpol Provinsi Banten belum mengetahui terkait dengan kebijakan tersebut. Kami Badan Kesbangpol Provinsi Banten baru mendengar adanya Inpres tersebut. Pelaksanaan program bela negara yang saat ini laksanakan oleh kami lebih menyasar pada pelajar dan mahasiswa yang biasanya kami melakukan pembekalan, dan kami rasa ini merupakan langkah dasar guna membimbing generasi penerus kedepan." (Wawancara Agus Kasubid Wasbang Kesbangpol Provinsi Banten, 3 Mei 2019)

Oleh karenanya, perlunya perbaikan sinergitas antara penyelenggara baik pemerintah pusat dan pemerintah daerah serta lembaga penyelenggara lainnya guna mengoptimalkan perubahan mewujudkan kehidupan berbangsa dan bernegara yang sejalan dengan nilai-nilai Pancasila. Adapun Yudi Latif juga berpendapat mengenai pentingnya sinergisitas yang terbangun antara lembaga penyelenggara:

"Penguatan pemahaman nilai-nilai kebangsaan tentu harus dilakukan dengan sinergis antara lembaga pemerintah pusat dan pemerintah daerah dikarenakan pemerintah 
pusat ataupun daerah merupakan perwujudan atas kedaulatan rakyat, serta wujud dari tata kehidupan yang lebih adil dan sejahtera. Dalam hal pemerintah tidak boleh berbeda dan tidak sinergis guna mewujudkan perwujudan tersebut." (Wawancara tertulis dengan Yudi Latif selaku Akademisi, pada 8 April 2019)

Sebagai cerminan daripada kedaulatan rakyat, serta perwujudan dari tata kehhidupan yang lebih adil dan sejahtera. Seharusnya lembaga penyelenggara baik pemerintah pusat ataupun pemerintah daerah saling bergerak sinergis dalam upaya mengembalikan semangat bela negara dan jati diri bangsa Indonesia.

\section{E. SIMPULAN DAN SARAN}

\section{Kesimpulan}

Akutnya krisis bangsa

Indonesia saat ini tentu merupakan gambaran atas belum seriusnya pemerintah dalam mewujudkan kehidupan bernegara yang kental akan nilai-nilai Pancasila. Akibatnya masyarakat saat ini mengalami pelemahan pemahaman nilai-nilai kebangsaan yang justru lebih fanatik terhadap ide-ide bernegara dari bangsa lain. Tentu hal ini dapat mengancam keutuhan Negara Kesatuan Republik Indonesia. Belum optimalnya penguatan pemahaman nilai-nilai kebangsaan juga dilihat dari belum sinergisnya lembaga penyelenggara baik pemerintah pusat ataupun pemerintah daerah terkait dalam melaksanakan Rencana Aksi Nasional Bela Negara. Belum sinergisnya pola hubungan dan kekompakan antar lembaga ini ditunjukkan dengan tidak mengetahuinya pemerintah daerah Provinsi Banten mengenai kebijakan Instruksi Presiden Nomor 7 Tahun 2018 mengenai Rencana Aksi Nasional Bela Negara, sehingga gaya pelaksanaan bela negara yang dilaksanakan saat ini masih merujuk pada modul lama. Oleh karena perubahan ideal yang diinginkan oleh pemerintah pusat mengalami perlambatan akibat dari sinergitas yang belum terbangun dengan baik. Selain itu kedudukan terkait Rencana Aksi Nasional Bela Negara yang masih berada pada level Instruksi Presiden belum menunjukkan keseriusan yang optimal dalam mencegah adanya ancaman disintegrasi bangsa. Oleh karena akutnya krisis bangsa Indonesia yang melanda saat ini, seharusnya perlu ditempatkan pada kedudukan hukum yang ideal.

\section{Saran}

Berdasarkan hasil studi lapangan, observasi, dan wawancara yang dilakukan oleh peneliti, peneliti menemukan beberapa saran yang diharapkan dapat membangun ideide ke arah yang lebih baik dan bersifat membangun. Saran ini tentunya ditujukan kepada seluruh elemen pemerintahan yang berwenang melaksanakan aksi bela negara, yaitu a) tempatkan kedudukan hukum mengenai penguatan nilai-nilai kebangsaan pada level yang lebih ideal, yang menurut hemat peneliti adalah 
Undang-undang. Hal ini tentu dapat lebih memasifkan kembali penguatan nilai-nilai kebangsaan pada masyarakat; b) perlu adanya dorongan dari pemerintah pusat guna memberikan semangat bagi pemerintah di tiap-tiap daerah untuk ikut serta dalam pelaksanaan bela negara berdasarka Instruksi Presiden Nomor 7 tahun 2018; c) program pelaksanaan Rencana Aksi Nasioanal Bela Negara seharusnya menjadi alternative baru bagi pelaksanaan penguatan nilai-nilai kebangsaan sebelumnya yang hanya bersifat sosialisasi dan sejenisnya, perlu ada program yang tidak bersifat kaku (doktriner) sehingga dapat diterima oleh masyarakat pada umumnya, khususnya Generasi Milenial; d) membentuk forum atau kongres kebangsaan di Provinsi Banten yang melibatkan Cendekiawan di Banten, Akademisi, Budayawan, kelompokkelompok kepemudaan, Tokoh Masyarakat, dan elemen masyarakat lainnya, yang nantinya akan memberikan rekomendasi sebagai masukan bagi pemerintah, tentu dalam pelaksanaan ini nantinya perlu diselenggarakan oleh Badan Kesbangpol Provinsi Banten yang dinilai lebih berwenang, yang dapat bekerjasama dengan Universitas di Banten; e) output nyata dari pelaksanaan Rencana Aksi Nasional kedepan adalah dengan dibentuknya Pusat Studi Kebangsaan di kampuskampus sebagai wahana bagi kaum intelektual kampus, akademisi, serta menghimpun kelompok-kelompok masyarakat lainnya dalam memberikan gagasan perihal penguatan nilai-nilai kebangsaan dan nilai-nilai Pancasila; f) membentuk kemasan kegiatan yang dapat diterima oleh kalangan-kalangan Milenial, yang tidak hanya bersifat doktriner dan pasif. Kemasan kegiatan seperti Touring Motor dengan tujuan mengenal lebih jauh karakteristik wilayah-wilayah yang ada di Indonesia. Kegiatan-kegiatan keolahragaan, seperti Porseni yang seharusnya diselenggarakan lebih sering guna menyatukan rasa kekeluargaan didalam kehidupan bernegara. Tentu kegiatan-kegiatan seperti ini dapat dilaksanakan oleh Pemerintah, misalnya Dinas Pemuda dan Olahraga.

\section{DAFTAR PUSATAKA}

\section{Buku}

Agustino, Leo. 2017. Dasar-dasar Kebijakan Publik . Bandung : CV. ALFABETA

Creswell, John. 2014. Penelitian Kualitatif dan Desain Riset. Yogyakarta : Pustaka Pelajar.

Fuad, Anis \& Nugroho S. Kandung. 2014. Panduan Praktis Penelitian Kualitatif.

Yogyakarta: Graha Ilmu.

Heywood, Andrew. 2016. IDEOLOGI POLITIK. Yogyakarta : Pustaka Pelajar

Ir. Soekarno. 2017. Filsafat Pancasila menurut Bung Karno. Yogyakarta : Media Pressindo

Ir. Soekarno. 2014. Panca Azimat Revolusi Jilid I. Jakarta : KPG (Kepustakaan Populer Gramedia) 
Kemenristekdikti, 2016. Pendidikan Pancasila Untuk Perguruan Tinggi.

Latif, Yudi. 2016. Mata Air Keteladanan : Pancasila dalam Perbuatan. Jakarta : Mizan.

Latif, Yudi.2011. NEGARA PARIPURNA (historisitas, rasionalitas, dan aktualitas Pancasila). Jakarta : PT Gramedia Pustaka Utama.

Latif Yudi. 2017. Revolusi Pancasila : Kembali ke Rel Perjuangan Bangsa. Jakarta : Mizan.

Latif Yudi. 2018. Wawasan Pancasila.

Jakarta : Mizan.

Raco, J. R l. 2010. Metode Penelitian Kualitatif (Jenis, Karakteristik, dan

Keunggulan). Jakarta: Grafindo Sastrapratedja, M. 2001. Pancasila

Sebagai Visi dan Referensi

Kritik Sosial. Yogyakarta: Universitas Senata Dharma.

Syahrul Hermawan dan Nilamsari

Endang. 2009. STAR

REVOLUTION. Jakarta : PT. ARGA TILANTA

Sugiyono. 2009. Memahami

Penelitian Kualitatif. Bandung: Penerbit Alfabeta.

Sugiyono. 2018. Metode Penelitian

Kuantitatif, Kualitatif dan R \&

D. Bandung: Alfabeta.

Suharto, Edi. 2005. Analisis Kebijakan Publik. Jawa Barat : ALFABET

\section{Jurnal}

Fanani, Muhyar. 2017. THE IMPACT OF THE DECLINING PANCASILA DEMOCRACY IN THE POST- INDONESIA
REFORMATION. Advances in Social Science, Education and Humanities Research (ASSEHR), vol 129. Third International Conference on Social and Political Sciences (ICSPS 2017)

Hikmawan, M. Dian. Politik Perbedaan : Minoritas dalam Implementasi Kebijakan. Jurnal of Indonesian Public Administration and Governance Study (JIPAGS).

Ibrahim, Anis. 2010. PERSPEKTIF FUTURISTIK PANCASILA SEBAGAI ASAS/IDEOLOGI DALAM UU KEORMASAN. Vol, III. No. 2. Jurnal Konstitusi. PUSKASI FH UNIVERSITAS WIDYAGAMA MALANG

Tjiptabudy, J. KEBIJAKAN PEMERINTAH DALAM UPAYA MELESTARIKAN NILAI-NILAI PANCASILA DI ERA REFORMASI. (Jurnal Sasi Vol.16. No.3 Bulan Juli September 2010)

Winarno, dan Moh. Muchtarom. 2017. The Ideology of Nationalism in Indonesia Civic Education Textbook. International Journal of Humanities and Social Science Invention, vol 6 issue 9.

Zabda, S. Sutan. Jurnal Pendidikan Ilmu Sosial. Aktualisasi Nilainilai Pancasila sebagai Dasar Falsafah Negara dan Implementasinya Dalam Pembangunan Karakter Bangsa. (vol. 26, no. 2, Desember 2016) 


\section{Perundang-undangan}

Instruksi Presiden Nomor 7 Tahun 2018 mengenai Rencana Aksi Nasional Bela Negara.

\section{Internet}

http://sejarahlengkap.com/dunia/sej arah-runtuhnya-uni-soviet (diakses pada: kamis, 27/09/2018, pukul : 08.19 WIB)

http://wawasansejarah.com/politikapartheid-di-afrika-selatan/ (diakses pada: Kamis, 27/09/2018. Pukul : 10.58 WIB)

http://setkab.go.id/wpcontent/uploads/2018/09/In pres-Nomor-7-Tahun-20183.pdf (diakses pada: Selasa, 30/10/2018. Pukul: 16.47 WIB)

https://nasional.kompas.com/read/2 018/05/22/15102061/presid en-jokowi-hampir-semuanegara-menghadapi-ancamanterorisme (diakses pada: Kamis, 24/1/2019. Pukul: $03.00 \mathrm{WIB}$ )

https://www.bantenprov.go.id

(diakses pada: Rabu, 10/5/2019. Pukul: 22.10 WIB) https://sidaltaru.bantenprov.go.id

(diakses pada: Rabu, 10/5/2019. Pukul: 23.35 WIB) https://kesbangpol.bantenprov.go.id (diakses pada: Rabu, 13/6/2019. Pukul: 20.00 WIB)

\section{Media Lain}

Riswanda. 2018. EMPAT KONSENSUS

DASAR

KEHIDUPAN

BERBANGSA

DAN

BERNEGARA: SEBUAH

TELAAH KRITIS. Komando Resor Militer 064 Maulana Yusuf.

Dewan Ketahanan Nasional. 2018. MODUL UTAMA PEMBINAAN BELA NEGARA (KONSEPSI BELA NEGARA) 